\title{
Seasonal variations in response of periphytic algal community to nutrient enrichment in the river Ganga (Varanasi, India)
}

\author{
Arpana Yadav ${ }^{1, *}$, Dhananjay Kumar ${ }^{2}$, Ram Sharan Singh ${ }^{3}$, Lalit K. Pandey ${ }^{4}$ and Jyoti Rai ${ }^{1}$ \\ ${ }^{1}$ Laboratory of Algal Biology, Department of Botany, Institute of Science, Banaras Hindu University, Varanasi 221005, India \\ 2 Department of Botany, School of Life Sciences, H.N.B. Garhwal University, Srinagar, Garhwal 246174, India \\ 3 Department of Chemical Engineering and Technology, Indian Institute of Technology (BHU), Varanasi 221005, India \\ ${ }^{4}$ Department of Plant Science, Faculty of Applied Sciences, MJP Rohilkhand University, Bareilly 243006, India
}

Received: 19 September 2017; Accepted: 18 September 2018

\begin{abstract}
Effect of nutrient enrichment on periphyton was studied using chemical diffusing substrates that released, singly or in combination, $\mathrm{PO}_{4}{ }^{3-}-\mathrm{P}$ and nitrogen, both $\mathrm{NO}_{3}{ }^{-}-\mathrm{N}$ and $\mathrm{NH}_{4}{ }^{+}-\mathrm{N}$. The study was carried out in March and June 2014 as these two time periods showed abundance of different groups of algae. Whereas diatoms and green algae were abundant in March, cyanobacteria dominated in June. Nitrogen was primarily growth limiting in river water as its enrichment enhanced the growth of periphyton. Phosphate limitation was secondary in nature. Enrichment of $\mathrm{NH}_{4}{ }^{+}-\mathrm{N}$ caused greater enhancement of periphytic growth than that of $\mathrm{NO}_{3}{ }^{-}-\mathrm{N}$. Nutrient enrichment reduced species diversity, further enhancing total biovolume of the periphytic group that was predominant at that particular point of time. Nutrient enrichment markedly increased cyanobacterial populations in June due inter alia to high temperature. In spite of nutrient enrichment, the periphytic biomass did not reach the level (chl $a \geq 100-150 \mathrm{mg} \mathrm{m}^{-2}$ ) considered as the nuisance, except in March when combined enrichment of $\mathrm{PO}_{4}{ }^{3-}-\mathrm{P}$ and $\mathrm{NO}_{3}{ }^{-}-\mathrm{N}_{\text {greatly }}$ enhanced the periphytic biomass.
\end{abstract}

Keywords: periphyton / chemical diffusing substrate / nutrient limitation / nitrogen / phosphorus

\section{Introduction}

Eutrophication of water bodies is a major environmental problem in many parts of the world (Dodds and Smith, 2016). It results from enrichment of waterbodies with nutrients that trigger excessive and undesirable growth of algae and plants (Stevenson et al., 2012). Nutrient enrichment is primarily due to input of domestic wastes and other nutrient-loaded wastewaters (point sources) or run off from fertilizer-enriched agricultural fields or other areas (non-point sources) into waterbodies. Many lakes, streams and rivers across the world are becoming increasingly eutrophic and hence are greatly suffering due to deterioration of water quality (Dodds, 2003; Dodds and Smith, 2016). In coastal regions, including estuaries, eutrophication has been identified as a major environmental problem (Lyon and Ziegler, 2009; Paerl et al., 2014). Although eutrophication is prevalent in almost every part of the world, the problem is alarming in developing countries that do not have enough financial resources for proper waste treatment and disposal (Ansari et al., 2011).

Nitrogen and phosphorus are important nutrients that cause eutrophication if present in high concentrations in aquatic

\footnotetext{
*Corresponding author: yadavarpana26@gmail.com
}

ecosystems. In natural aquatic ecosystems, these nutrients often occur at low concentrations, which are limiting for the growth of algae (Tank and Dodds, 2003; Elser et al., 2007). To study whether nitrogen or phosphorus limits the algal growth, in situ studies have been done in lentic and lotic ecosystems (Tank and Dodds, 2003; Death et al., 2007). In this context, lentic ecosystems, showing a well-established relationship between nutrient concentration and planktonic algal biomass, have received a lot of attention of limnologists (Vollenweider, 1976). Establishing nutrient criteria in lotic ecosystems is however difficult due to continuous unidirectional flow of water and also because many environmental factors affect the autotrophic biomass, including shading, light, nutrient and current velocity fluctuations (Jarvie et al., 2002; Proia et al., 2012; Townsend et al., 2012). Nevertheless, studies demonstrate a positive correlation between benthic algal biomass and nutrient concentration in water column (Dodds et al., 2002; Dodds and Smith, 2016).

Periphyton constitutes an important component of primary producers in lotic ecosystems (Petersen et al., 2018). Due to attached nature, rapid growth and marked sensitivity to environmental perturbations, they are sensitive indicators of water quality (Hill et al., 2001; Pfeiffer et al., 2013). Understanding how nutrients limit periphyton growth has 
for long been the subject of interest to stream and river ecologists (Keck and Lepori, 2012). According to singlenutrient paradigm (Liebig's law of minimum), only one nutrient, shortest in supply relative to its need, limits the biomass production in autotrophs (Paerl et al., 2014). However, application of single-nutrient paradigm to multispecies periphytic communities is not strictly valid (Keck and Lepori, 2012) as algal species differ in their nutrient requirements and different species could be limited by different nutrients. Many in situ studies have been done to investigate the impact of nutrient enrichment on periphytic algae (Tank and Dodds, 2003; Lawrence et al., 2004; Teissier et al., 2007). Earlier it was a paradigm that $\mathrm{P}$ is only growth limiting nutrient in freshwaters. However, recent metaanalysis studies (Francoeur, 2001; Elser et al., 2007) explain that in multispecies community both limiting and nonlimiting nutrients enhance the biomass and $\mathrm{N}$ was approximately equally likely as $\mathrm{P}$ to be limiting.

Determination of limiting nutrient in lotic ecosystems is also difficult due to great temporal variations in the environment. Since nutrient concentrations as well as nutrient ratios vary seasonally, it is imperative to study seasonal variations of nutrient limitation. Up to now, only a few workers have studied the seasonal variation of nutrient enrichment effect on periphyton (Franca et al., 2009; Casartelli and Ferragut, 2015) and there is a need for further research in this area. The pattern of nutrient limitation also varies among systems across the globe. Previous studies conclude that whether $\mathrm{N}$ or $\mathrm{P}$ limits growth depends upon climatic conditions, catchment geology and biogeography of a region (Tank and Dodds, 2003; Death et al., 2007; Stevenson et al., 2012). Though a lot of research has been carried out in temperate countries, very few studies have been done in tropical countries, particularly in south and southeast Asia, including India. Thus, it is necessary to carry out experiments in different geographical regions and climatic conditions for a better understanding of nutrient limitation pattern.

The river Ganga is one of the most important rivers in India influencing lives of approximately $40 \%$ Indians inhabiting its drainage area (Jin et al., 2015). The river receives treated/ untreated municipal sewage from various cities, industrial effluents and other kinds of wastes along its about $2510 \mathrm{~km}$ long journey commencing from Gangotri, in the state of Uttarakhand, to the Bay of Bengal. The river has become severely polluted and this has become a matter of great concern for the common public as well as the government (Whitehead et al., 2015). The Government of India has been actively pursuing the task of remediation of this river by forming appropriate bodies and also making huge investments in various remedial activities (Whitehead et al., 2015). Another very important action with respect to the management of this river is regular monitoring of its water quality.

In view of the possibility that in future the concentration of nutrients may increase in the river Ganga, a nutrient enrichment study was carried out on periphytic communities of this river at Varanasi, India. The study investigates the impact of the single and interactive effects of phosphate, nitrate and ammonia enrichment on biomass, community composition and diversity of periphyton in different seasons of a year. Seasonal studies on nutrient limitation of benthic algae have received only a little attention up to now and a majority of these have focused on biomass responses of periphyton and changes in taxonomic composition and diversity has been less addressed. Moreover, in the present investigation, attempt has been made to compare the effect of both $\mathrm{NO}_{3}{ }^{-}-\mathrm{N}$ and $\mathrm{NH}_{4}{ }^{+}-\mathrm{N}$ on lotic periphytic community structure, which was rarely studied earlier.

The present study addresses the following questions: (i) Whether $\mathrm{N}$ and/or P limits the growth of periphytic algae in the river Ganga, at Varanasi, India. (ii) Does seasonality affect responses of various periphytic groups and taxa to nutrient amendments and if so, how?

\section{Study area}

Nutrient enrichment experiments were carried out in March (spring) and June (summer) 2014 in the river Ganga at a site near Garhwa Ghat, Ramna, a village of Varanasi in the eastern part of the state of Uttar Pradesh in India. Varanasi city $\left(25^{\circ} 18^{\prime} \mathrm{N}, 83^{\circ} 01^{\prime} \mathrm{E}\right.$; and $80.71 \mathrm{~m}$ above mean sea level) lies in the middle stretch of Ganges river basin in the northern part of India. The climate of the town is tropical monsoon with total rainfall $\sim 1100 \mathrm{~mm}$. During the course of the experiment, the average minimum and maximum atmospheric temperatures were $16.8^{\circ} \mathrm{C}$ and $37.7^{\circ} \mathrm{C}$ and 26.5 and $46^{\circ} \mathrm{C}$ during March and June 2014 , respectively. The study site has extensive farmland around it, which supports farming of various vegetable crops and pulses. Besides farming, the river water is also used for various recreational and subsistence activities, including fishing, agriculture, animal husbandry, fish farming, bathing, washing clothes and bathing of animals. Fishing is the most important activity at this study site.

\section{Materials and methods}

\subsection{Experimental design}

To study the effects of nutrients on periphyton, chemical diffusing substrates (CDS) were constructed (Fig. 1). CDS were made using conical plastic funnels (height $8 \mathrm{~cm}$, diameter $14 \mathrm{~cm}$ at the base, internal volume $600 \mathrm{ml}$ ) and a circular unglazed and fired clay tile (diameter $15 \mathrm{~cm}$; thickness $4 \mathrm{~mm}$ ) following the method described by Pandey et al. (2014). The wide mouth of each funnel was sealed with clay tile using an epoxy resin (m-seal, Pidilite Industries, Mumbai), making a reservoir for nutrient solution while its narrow opening was closed with a rubber stopper (Fig. 1). The constructed CDS were then filled with one of the following nutrient solutions: $\mathrm{PO}_{4}{ }^{3-}-\mathrm{P}\left(0.1 \mathrm{M} \mathrm{NaH}_{2} \mathrm{PO}_{4}\right), \mathrm{NO}_{3}{ }^{-}-\mathrm{N}\left(0.5 \mathrm{M} \mathrm{NaNO}_{3}\right), \mathrm{NH}_{4}{ }^{+}-$ $\mathrm{N}\left(0.5 \mathrm{M} \mathrm{NH}_{4} \mathrm{Cl}\right), \mathrm{NO}_{3}{ }^{-}-\mathrm{N}+\mathrm{PO}_{4}{ }^{3-}-\mathrm{P}\left(0.5 \mathrm{M} \mathrm{NaNO}_{3}+0.1 \mathrm{M}\right.$ $\left.\mathrm{NaH}_{2} \mathrm{PO}_{4}\right)$, and $\mathrm{NH}_{4}{ }^{+}-\mathrm{N}+\mathrm{PO}_{4}{ }^{3-}-\mathrm{P}\left(0.5 \mathrm{M} \mathrm{NH} \mathrm{NH}_{4} \mathrm{Cl}+0.1 \mathrm{M}\right.$ $\mathrm{NaH}_{2} \mathrm{PO}_{4}$ ). CDS filled with only river water served as the control. When kept in water, these CDS diffused nutrient ions via the porous clay surface, which also served as the substratum for the attachment, colonization and growth of periphytic algae.

Initially, a laboratory experiment was carried out to determine the rate of release of $\mathrm{NO}_{3}{ }^{-}-\mathrm{N}, \mathrm{PO}_{4}{ }^{3-}-\mathrm{P}$ and $\mathrm{NH}_{4}{ }^{+}$$\mathrm{N}$ through CDS following the method given in Fairchild et al. (1985). For this purpose, CDS for each of the different nutrient treatments, i.e. $\mathrm{PO}_{4}{ }^{3-}-\mathrm{P}\left(0.1 \mathrm{M} \mathrm{NaH}_{2} \mathrm{PO}_{4}\right), \mathrm{NO}_{3}{ }^{-}-\mathrm{N}(0.5 \mathrm{M}$ $\left.\mathrm{NaNO}_{3}\right)$ and $\mathrm{NH}_{4}{ }^{+}-\mathrm{N}\left(0.5 \mathrm{M} \mathrm{NH} \mathrm{N}_{4} \mathrm{Cl}\right)$, were placed in waterfilled plastic buckets $(4 \mathrm{~L})$. The water with diffused nutrient ions was then sampled after every $24 \mathrm{~h}$, analysed for $\mathrm{PO}_{4}{ }^{3-}-\mathrm{P}, \mathrm{NO}_{3}{ }^{-}-$ 
(a)

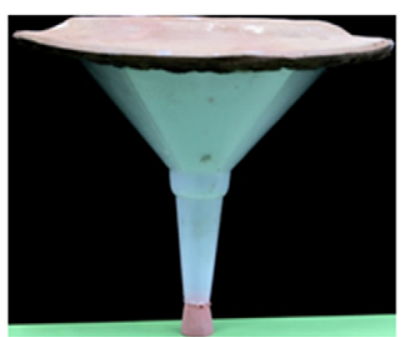

(c)

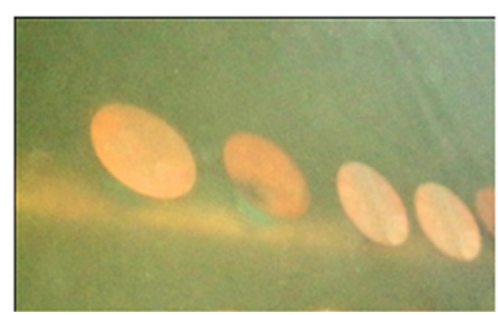

(b)

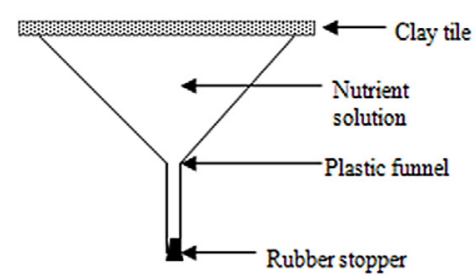

(d)

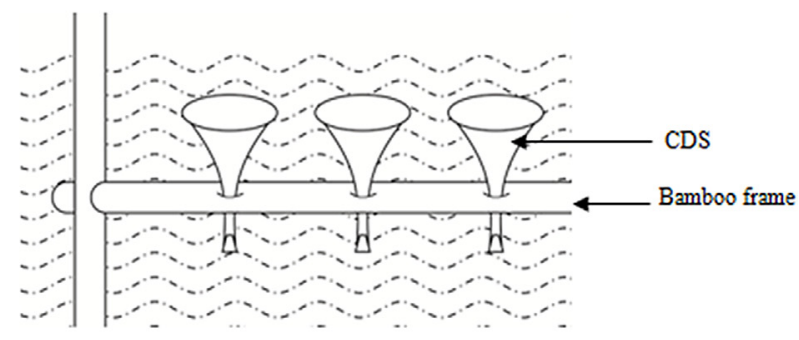

Fig. 1. Photographs and schematic diagrams of chemical diffusing substrate and experimental setup deployed in river. (a) Photograph of a CDS. ( b) Schematic diagram of CDS. (c) Photograph of a section of experimental unit deployed in river. (d) Schematic diagram of a section of experimental unit deployed in river showing CDS secured in bamboo frame.

$\mathrm{N}$ or $\mathrm{NH}_{4}{ }^{+}-\mathrm{N}$ and then renewed. Three replicates were employed for each nutrient treatment and the experiment lasted 20 days.

The experiment was set up at the selected study site in the river Ganga at Garhwa Ghat, Varanasi, India. The constructed CDS were deployed in river using bamboo frame (Fig. 1) and left for 20 days for the colonization and growth of periphytic algae. CDS were mounted perpendicularly in bamboo frame in such a manner that their clay surface was lying parallel to water surface (Fig. 1). The substrates were fixed at a depth of $10 \mathrm{~cm}$ below the water surface and $10 \mathrm{~m}$ away from the river bank. The experiment was performed in two different study periods; March as well as in June. Although 1-2 week time period has been considered as sufficient to discern the effect of nutrient enrichment on periphyton (Biggs and Kilroy, 2000), the present study was carried out for 20 days with sampling at 5day time intervals.

\subsection{Collection and analysis of river water}

Physicochemical parameters of river water were measured regularly at weekly interval in both the study periods. The water samples were collected in triplicate, kept in an ice box and transported to the laboratory within $20 \mathrm{~min}$ of sampling. Water samples were analysed for temperature, $\mathrm{pH}$, conductivity, total dissolved solid (TDS), flow rate, phosphatephosphorus $\left(\mathrm{PO}_{4}{ }^{3-}-\mathrm{P}\right)$, total phosphorus (TP), nitrate-nitrogen $\left(\mathrm{NO}_{3}{ }^{-}-\mathrm{N}\right)$, nitrite-nitrogen $\left(\mathrm{NO}_{2}{ }^{-}-\mathrm{N}\right)$, ammonia-nitrogen $\left(\mathrm{NH}_{4}{ }^{+}-\mathrm{N}\right)$ and dissolved silica following standard widely used protocols (Wetzel and Likens, 2000). Temperature, $\mathrm{pH}$, conductivity and TDS were measured in situ with appropriate portable devices (Hanna Hi98509 digital thermometer, Hanna $\mathrm{pHep}^{\circledR} \mathrm{pH}$ tester, ISO Tech System ITS, ITS-302 TDS conductivity meter, Milwaukee M10031B conductivity meter). Flow rate was measured via velocity-area method (Gordon et al., 2013) using a low-density styrofoam float. Soluble reactive phosphorus was analysed following the ascorbic acid method. Total phosphorus was also measured by the ascorbic acid method after digestion of water samples with persulfate. $\mathrm{NO}_{3}{ }^{-}-\mathrm{N}$ was reduced to nitrite by cadmium-reduction column and $\mathrm{NO}_{2}{ }^{-}-\mathrm{N}$ was thereafter measured by the diazotization method. Ammonium nitrogen in water sample was determined by the phenol-hypochlorite method and dissolved silica estimated using the molybdate method.

\subsection{Collection and study of periphyton}

Periphytic algae were sampled 5, 10, 15 and 20 days after deployment of CDS in the river Ganga. The sampling was done in triplicate by scraping an area of $40 \mathrm{~cm}^{2}$ of the colonized periphytic biofilm on each CDS with a sharp razor blade and a toothbrush with hard bristles. The samples were collected in plastic screw cap tubes and diluted to a constant final volume up to $8 \mathrm{ml}$ using distilled water. The algal samples were then homogenised by vigorous shaking and divided into three subsamples. The first subsample was subjected to chlorophyll $a$ (chl a) estimation, the second preserved with $4 \%$ formaldehyde solution for taxonomic analyses and the third one used for microscopic examination of live material. Chlorophyll $a$ was estimated using the trichromatic method given in Strickland and Parsons (1968) after extraction in 90\% acetone and storage for $24 \mathrm{~h}$ in the dark.

Taxonomic analyses of periphytic samples were done by observing them under light microscope with an attached digital camera (Motic, BML series, Hong Kong) at a magnification $450 \times$ and $1000 \times$. At least 500 algal cell units were counted from each sample using a Spencer's Bright-Line haemocytometer and identified to species level following appropriate literature, such as Phillipose (1967), Desikachary (1959), Prescott (1962, 1978), Patrick and Reimer (1966, 1975), Cox (1996), AlgaeBase (http://www.algaebase.org) and ANSP algal image data base (http://diatom.acnatsci.org/AlgaeImage/). An algal cell unit was defined as an individual cell for unicellular green algae and diatoms, each cell of filament for large filamentous green algae and an area of $10 \times 10 \mu \mathrm{m}^{2}$ in case of 
Table 1. Mean rate of release and standard error (mean $\pm \mathrm{SE}$ ) of $\mathrm{NO}_{3}{ }^{-}-\mathrm{N}, \mathrm{NH}_{4}{ }^{+}-\mathrm{N}$ and $\mathrm{PO}_{4}{ }^{3-}-\mathrm{P}$ from CDS.

\begin{tabular}{|c|c|c|c|}
\hline Duration of release (days) & $\begin{array}{l}\mathrm{NO}_{3}{ }^{-}-\mathrm{N} \\
\left(\mathrm{mg} \mathrm{L}^{-1} \mathrm{~d}^{-1}\right)\end{array}$ & $\begin{array}{l}\mathrm{NH}_{4}^{+}-\mathrm{N} \\
\left(\mathrm{mg} \mathrm{L}^{-1} \mathrm{~d}^{-1}\right)\end{array}$ & $\begin{array}{l}\mathrm{PO}_{4}{ }^{3-}-\mathrm{P} \\
\left(\mathrm{mg} \mathrm{L}^{-1} \mathrm{~d}^{-1}\right)\end{array}$ \\
\hline $1-5$ & $21.47 \pm 0.30^{\mathrm{a}}$ & $22.42 \pm 0.32^{\mathrm{a}}$ & $2.19 \pm 0.05^{\mathrm{b}}$ \\
\hline $11-15$ & $11.40 \pm 0.19^{\mathrm{a}}$ & $13.96 \pm 0.19^{\mathrm{b}}$ & $1.41 \pm 0.01^{\mathrm{c}}$ \\
\hline $16-20$ & $5.55 \pm 0.22^{\mathrm{a}}$ & $10.78 \pm 0.22^{\mathrm{b}}$ & $1.11 \pm 0.03^{\mathrm{c}}$ \\
\hline ANOVA; $F_{(3,8)}$ & $650.45^{*}$ & $650.46^{*}$ & $392.97^{*}$ \\
\hline
\end{tabular}

Data in a row bearing different letters $\mathrm{a}, \mathrm{b}$ or $\mathrm{c}$ are significantly different $(p<0.05$; Tukey's HSD test) from each other. Data in the last row denote results of statistical analysis test by one-way ANOVA, indicating the effect of time on release rate of various nutrients.

${ }^{*}$ Indicates significant differences at $p<0.05$.

Table 2. Important physicochemical characteristics of river (Ganga) water during March and June 2014.

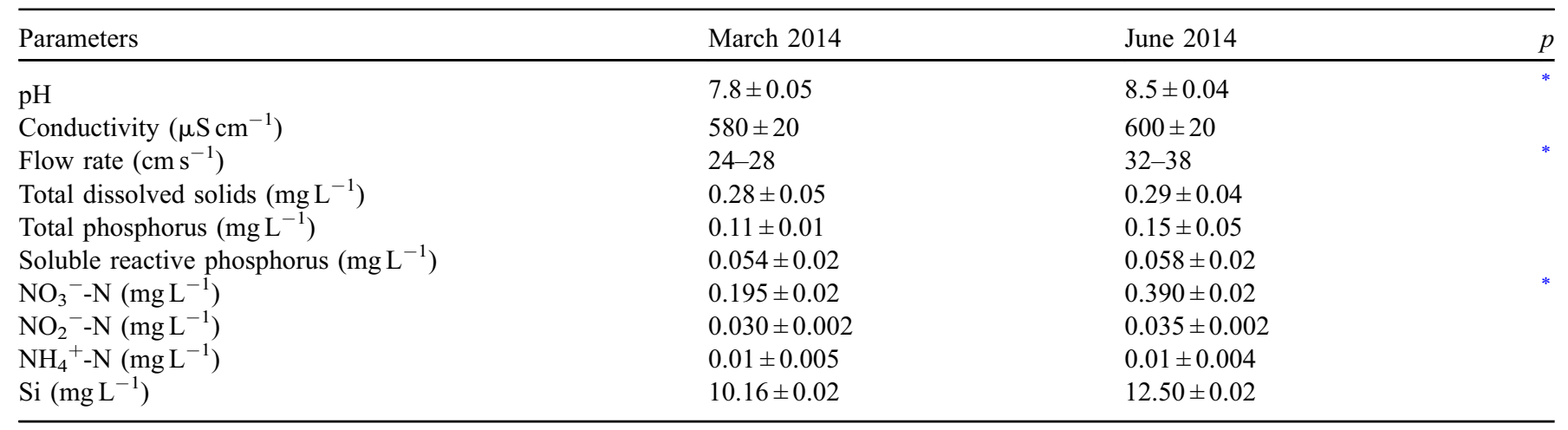

Data given are mean $\pm \mathrm{SE}$.

${ }^{*}$ Indicates significant differences of limnological parameters between seasons at $p<0.05$ (paired $t$-test).

algal colonies. For small filaments of cyanobacteria, a $10 \mu \mathrm{m}$ length was counted as one unit, since trichome crosswalls were not always apparent and thus counting individual cell would give unreliable results (DeNicola et al., 2006; Larson and Passy 2012). Filamentous green algae and cyanobacteria were directly counted and identified to species level, whereas diatoms were identified after preparing their permanent slides. The cell count data obtained were used for conversion into cell density and total cell biovolume. The mean biovolume for each taxon was calculated and converted to total biovolume by multiplying it to cell density. The biovolume of each periphytic taxa was calculated by measuring the average cell dimensions (length, width, height/diameter) with an ocular micrometer and entering the values in the appropriate geometric formulae that best described their three-dimensional shape (Hillebrand et al., 1999). A minimum of 10 individuals per algal species was taken to determine average cellular dimension. Total biovolume of the community was calculated by summing up the biovolume of all the individuals belonging to diverse species in the sample. The structure of periphytic community has been expressed in terms of species richness (total number of species in the community) and species diversity.

Data were statistically analysed by one-way analysis of variance (ANOVA) to test the significance of the effect of season, days and nutrient treatments on different periphytic attributes (biomass, total biovolume, species richness and diversity). Tukey's HSD test was done to test significance of differences of various nutrient treatments with the control as well as among different nutrient treatments $(\alpha<0.05)$. All the statistical tests were performed using the software SYSTAT13 (Systat Software, Inc., 2009). Species diversity, Shannondiversity index (Shannon, 1948), was calculated using the statistical software "Past" (Version 3.12; Natural History Museum, University of Oslo, Oslo).

\section{Results}

The mean rates of release $\left(\mathrm{mg} \mathrm{L}^{-1} \mathrm{~d}^{-1}\right)$ of $\mathrm{PO}_{4}{ }^{3-}-\mathrm{P}_{1} \mathrm{NO}_{3}{ }^{-}$$\mathrm{N}$ and $\mathrm{NH}_{4}^{+}-\mathrm{N}$ from CDS at 5-day time interval have been shown in Table 1. The rates of release of various nutrients were high during the beginning of the experiment, which consistently declined with the passage of time. $\mathrm{NH}_{4}{ }^{+}-\mathrm{N}$ and $\mathrm{NO}_{3}{ }^{-} \mathrm{N}$ were released at a considerably higher rate as compared to $\mathrm{PO}_{4}{ }^{3-}-\mathrm{P}$ (ANOVA, $F_{2,9}=10.13, p=0.01$ ).

Table 2 summarizes the important physicochemical parameters of water, measured during the course of the study, in the two seasons. Some of the parameters, such as $\mathrm{pH}$, flow rate and $\mathrm{NO}_{3}{ }^{-}-\mathrm{N}$ concentration differed significantly between the two seasons.

Figure 2 shows the biomass of algal periphyton, measured in terms of chl $a$, subjected to various nutrient enrichments. The biomass was low on day 5 , which consistently increased with the passage of time and the maximum biomass accrual 


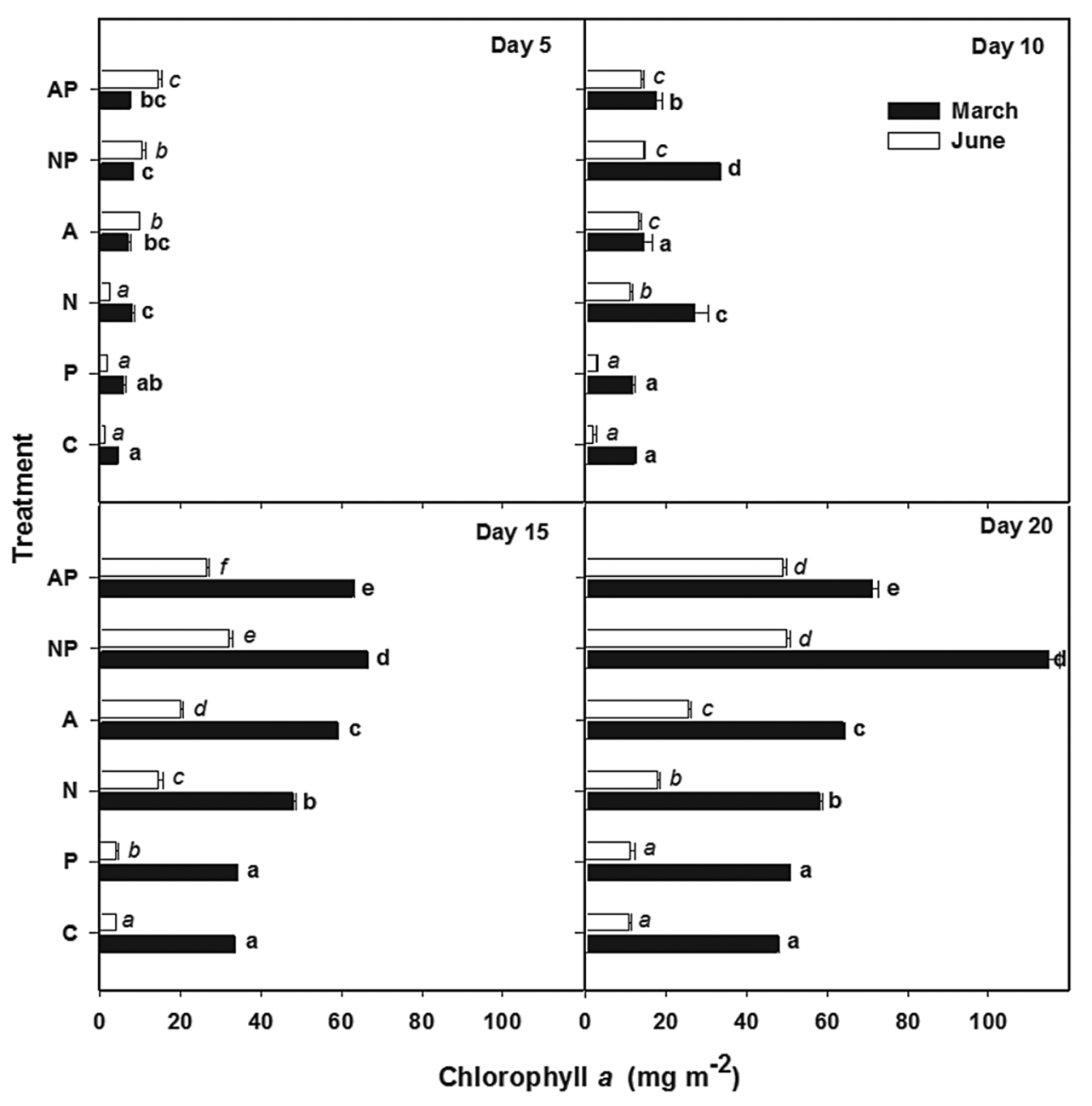

Fig. 2. Biomass (chl a) of periphyton subjected to various nutrient treatments: $\mathrm{C}=\mathrm{Control}, \mathrm{P}=\mathrm{PO}_{4}{ }^{3-}-\mathrm{P}, \mathrm{N}=\mathrm{NO}_{3}{ }^{-}-\mathrm{N}, \mathrm{A}=\mathrm{NH}_{4}{ }^{+}-\mathrm{N}$, $\mathrm{NP}=\mathrm{NO}_{3}{ }^{-}-\mathrm{N}+\mathrm{PO}_{4}{ }^{3}-\mathrm{P}$ and $\mathrm{AP}=\mathrm{NH}_{4}{ }^{+}-\mathrm{N}+\mathrm{PO}_{4}{ }^{3-}-\mathrm{P}$. Data bars marked with the same letter for a particular time period, bolds for March and italics for June, are not significantly different from each other $(p<0.05$; Tukey's HSD test).

was noticed on day 20. Statistics analysis by ANOVA showed significant differences in biomass between different sampling days (ANOVA, $F_{3,140}=37.00 ; p=0.00$ ). Biomass was higher in March than in June. In a majority of nutrient enrichments, excepting $\mathrm{PO}_{4}{ }^{3-}-\mathrm{P}$, significantly higher values of chl $a$ were observed as compared to the control, in both the seasons. $\mathrm{PO}_{4}{ }^{3-}$-P enrichment slightly enhanced the periphytic biomass, which was not statistically significant. In both the study periods, greatest biomass accumulation was observed in combined nutrient treatments. In March, the biomass attained maxima $\left(115 \pm 2.80 \mathrm{mg}\right.$ chl $\left.a \mathrm{~m}^{-2}\right)$ in $\mathrm{NO}_{3}{ }^{-}-\mathrm{N}+\mathrm{PO}_{4}{ }^{3-}-\mathrm{P}$ enrichment after 20 days. A relatively lower biomass represented the maxima ( $\left.50 \pm 0.85 \mathrm{mg} \mathrm{chl} a \mathrm{~m}^{-2}\right)$ in June after 20 days of experiment in $\mathrm{NO}_{3}{ }^{-} \mathrm{N}+\mathrm{PO}_{4}{ }^{3-}-\mathrm{P}$ and $\mathrm{NH}_{4}{ }^{+}$$\mathrm{N}+\mathrm{PO}_{4}{ }^{3-}$ - $\mathrm{P}$ enrichments. The total biovolume of periphytic algae (Fig. 3) showed a trend similar to that of biomass as it increased in various nitrogen treatments during both the experimental periods. Total periphytic biovolume was relatively greater in $\mathrm{NH}_{4}{ }^{+}-\mathrm{N}, \quad \mathrm{NO}_{3}{ }^{-}-\mathrm{N}+\mathrm{PO}_{4}{ }^{3-}-\mathrm{P}$ and $\mathrm{NH}_{4}{ }^{+}-\mathrm{N}+\mathrm{PO}_{4}{ }^{3-}-\mathrm{P}$ treatments than that in the controls or individual treatments of nitrogen and phosphorus at the end of 20 days of experiment in both March as well as in June.
The periphytic community on CDS comprised representatives of Chlorophyta (green algae), Bacillariophyta (diatoms) and Cyanobacteria (blue-green algae). The community composition exhibited slightly different patterns in the two study periods (Fig. 3). In March, during the initial phase of colonization, diatoms were the most abundant group (day 1-5) and the representation of other groups was negligible (Fig. 3). However, from day 10 onwards green algae became common and showed increased abundance on nutrient, releasing CDS. They were most represented $(>70 \%)$ on day 20 in periphytic community that developed on $\mathrm{NH}_{4}{ }^{+}-\mathrm{N}+\mathrm{PO}_{4}{ }^{3-}-\mathrm{P}$, releasing $\mathrm{CDS}$. The representatives of cyanobacteria occurred in small number but they showed enhanced total biovolume on nutrient diffusing CDS.

Contrary to March, in June, both diatoms and cyanobacteria were equally abundant during the initial phase (day 1-5) of colonization. Subsequently, cyanobacteria became the best represented group on CDS under diverse nutrient enrichments and the control. The members of this group responded positively to nutrient enrichment. They showed a relatively greater total biovolume in combined nutrient enrichments compared to single nitrogen enrichments. $\mathrm{NH}_{4}{ }^{+}-\mathrm{N}$ particularly 


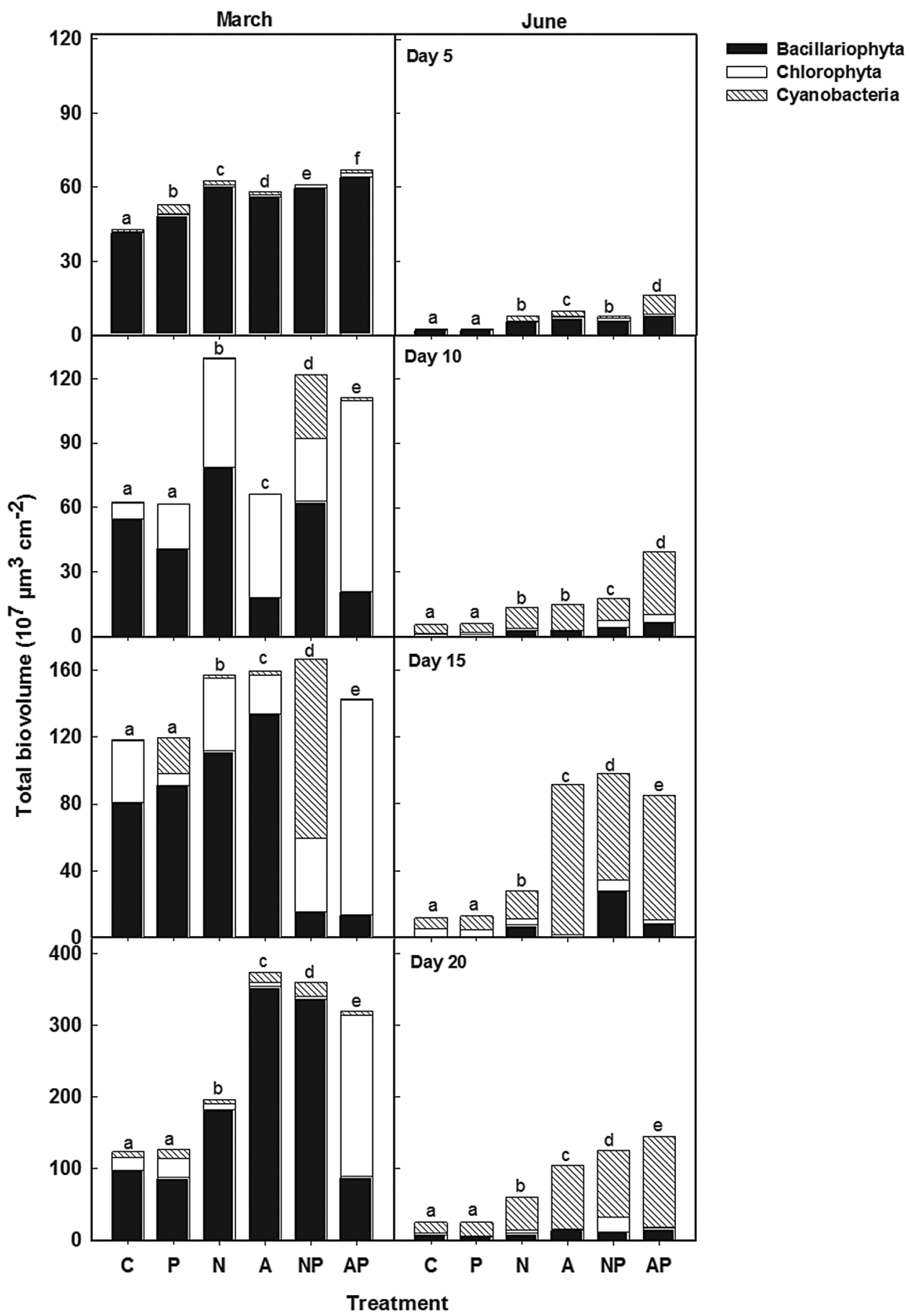

Fig. 3. Average total biovolume by major algal groups growing on nutrient-releasing CDS in March and June 2014. Details of nutrient treatment are given in Figure 2. Total biovolume data of the communities bearing the same letters are not significantly different from each other $(p<0.05$, Tukey's HSD test).

enhanced their total biovolume and their maximum total biovolume occurred on $\mathrm{NH}_{4}{ }^{+}-\mathrm{N}+\mathrm{PO}_{4}{ }^{3-}$-P-enriched CDS. Green algae occurred in small numbers and they also responded positively to various nutrient enrichments.

Species diversity of the periphytic community as measured by Shannon $H^{\prime}$ statistics varied between the two seasons and was greater in March than in June (Fig. 4). The number of species was also more in March than in June. Nutrient treatments had significant effect on species diversity (ANOVA, $\left.F_{5,138}=3.656, p=0.004\right)$ and it decreased in diverse nutrient treatments throughout the study period except a few instances, such as in $\mathrm{NO}_{3}{ }^{-}-\mathrm{N}$ treatment in March as well as in $\mathrm{NH}_{4}{ }^{+}-\mathrm{N}$ and $\mathrm{PO}_{4}{ }^{3-}-\mathrm{P}$ treatments June. Species richness, however, did not vary significantly with nutrient treatments (ANOVA, 


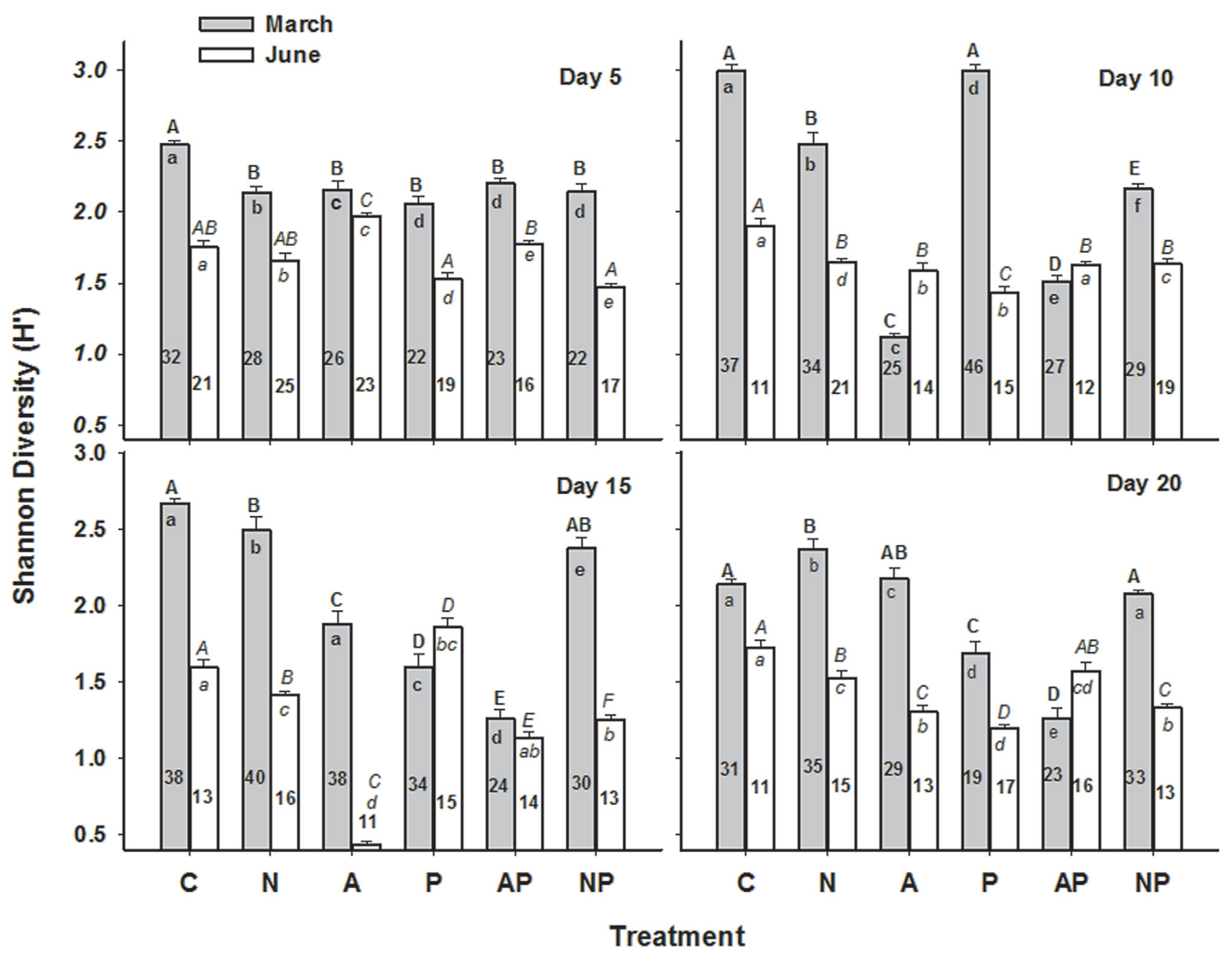

Fig. 4. Shannon diversity $\left(H^{\prime}\right)$ and species richness of periphytic community subjected to various nutrient enrichments in March and June 2014. The bars represent species diversity, whereas numbers inside the bars show the total number of periphytic species. Details of nutrient treatment are given in Figure 2. Data means bearing different letters for different seasons, bold for March and italics for June, are significantly different from each other at $p<0.05$ (Tukey's HSD test). The uppercase letters stand for shannon diversity and lowercase for species richness.

$\left.F_{5,138}=1.853, p=0.107\right)$ and it showed a slightly different pattern in March as well as in June. In March, a decrease in species richness generally occurred in various nutrient treatments as compared to the control with a few exceptions in nitrogen and phosphorus treatment (Fig. 4). Contrary to March, periphytic species richness increased in June in a majority of nutrient treatments (Fig. 4).

Figure 5 shows the responses of major diatom species in the community to various nutrient enrichments. The total biovolume of Nitzschia palea increased in all the nitrogen treatments. Its highest total biovolume was recorded on $\mathrm{NH}_{4}{ }^{+}-\mathrm{N}$ diffusing CDS in March. Differential response to nutrient treatment in various stages of colonization was displayed by some of the taxa, such as Cyclotella meneghiniana, whose total biovolume was increased by all the nutrient treatments initially up to day 10 . Nevertheless, it declined in all nutrient treatments, except for $\mathrm{NH}_{4}{ }^{+}-\mathrm{N}$ releasing substrate, at the end of the experiment. Some diatom taxa showed enhanced growth in all the nutrient treatments.
The total biovolume of Aulacoseira granulata increased in all the nutrient treatments in March and June. The total biovolume of Navicula recens decreased in all the nutrient treatments, except for $\mathrm{NO}_{3}{ }^{-}-\mathrm{N}$.

Green algae also varied in their response to various nutrient treatments (Fig. 6). The differential response of filamentous green algae Oedogonoium epiphyticum, Cladophora glomerata and Stigeoclonium tenue to $\mathrm{PO}_{4}{ }^{3-}-\mathrm{P}, \mathrm{NO}_{3}{ }^{-}-\mathrm{N}$ and $\mathrm{NH}_{4}{ }^{+}-\mathrm{N}$ enrichment was evident. The positive response of Oedogonium sp. was observed in $\mathrm{PO}_{4}{ }^{+}-\mathrm{P}, \mathrm{NO}_{3}^{-}-\mathrm{N}$ and $\mathrm{NO}_{3}{ }^{-}-\mathrm{N}+\mathrm{PO}_{4}{ }^{+}-\mathrm{P}$ treatments with greater total biovolume as compared to the control in both the study periods (ANOVA, $F_{5,60}=13.589$; $p=0.000$ ). Nevertheless, it disappeared on CDS releasing $\mathrm{NH}_{4}{ }^{+}$-N alone or in combination with $\mathrm{PO}_{4}{ }^{3-}$-P. On the contrary, S. tenue showed considerably enhanced abundance in $\mathrm{NH}_{4}{ }^{+}-\mathrm{N}$ and $\mathrm{NH}_{4}{ }^{+}-\mathrm{N}+\mathrm{PO}_{4}{ }^{3-}-\mathrm{P}$ treatments (ANOVA, $F_{5,66}=5.56$; $p=0.000$ ), but it remained absent on $\mathrm{NO}_{3}{ }^{-}-\mathrm{N}$ and $\mathrm{NO}_{3}{ }^{-}-$ $\mathrm{N}+\mathrm{PO}_{4}{ }^{3-}-\mathrm{P}$ releasing $\mathrm{CDS}$. Total biovolume of $C$. glomerata also increased significantly in all the nitrogen treatments, viz. 


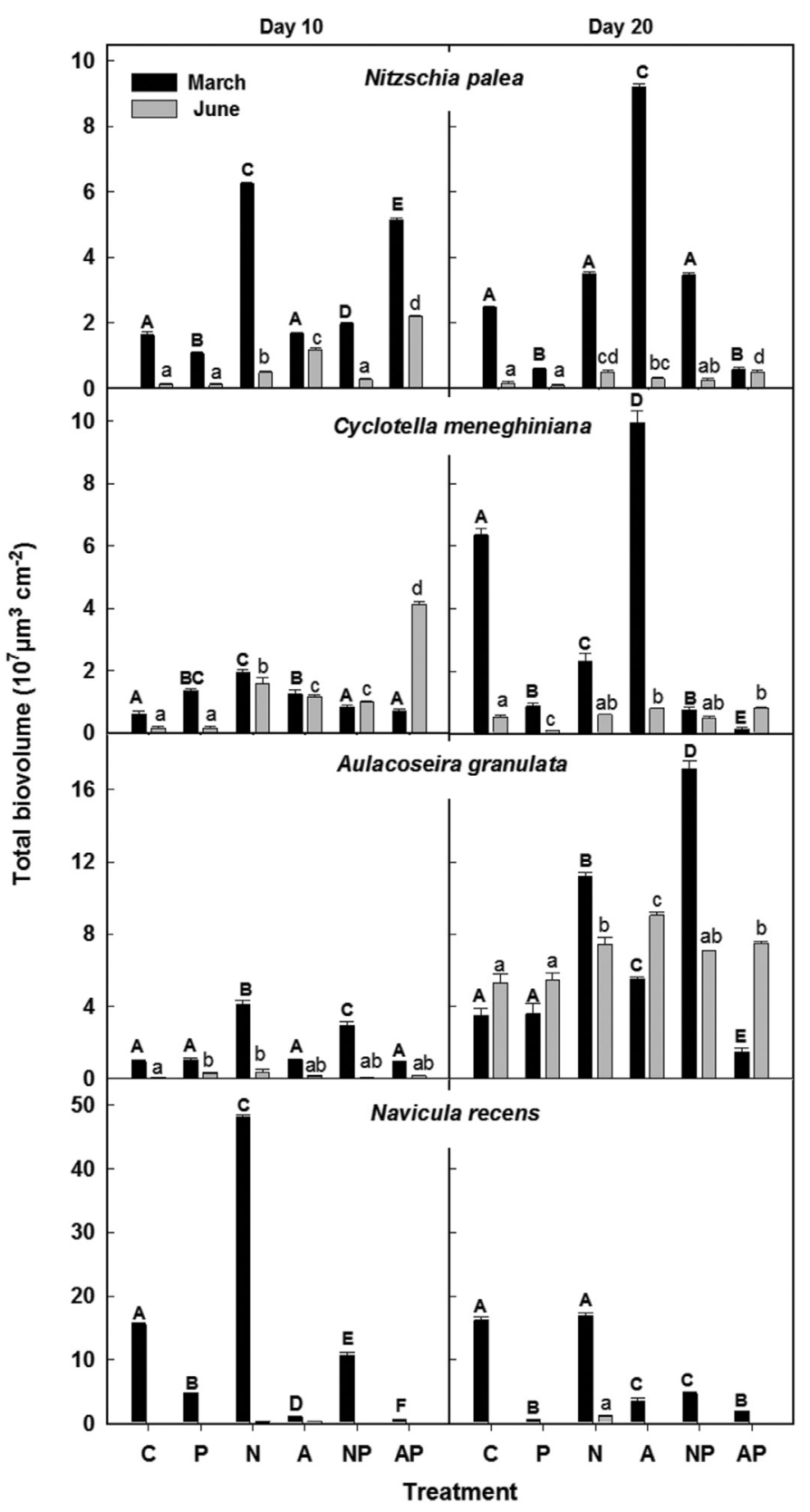

Fig. 5. Total biovolume of major diatom species in the periphytic community subjected to various nutrient enrichments in March and June 2014. Abbreviations for various treatments have been explained in Figure 2. Data are presented for day 10 and day 20 only. Data bearing different letters for different time periods are significantly different from each other ( $p<0.05$, Tukey's HSD test). The uppercase letters have been used for March, while lowercase for June.

$\mathrm{NO}_{3}{ }^{-}-\mathrm{N}, \mathrm{NH}_{4}{ }^{+}-\mathrm{N}, \mathrm{NO}_{3}{ }^{-}-\mathrm{N}+\mathrm{PO}_{4}{ }^{3-}-\mathrm{P}$ and $\mathrm{NH}_{4}{ }^{+}-\mathrm{N}+\mathrm{PO}_{4}{ }^{3-}$ $\mathrm{P}$, viz. in March (ANOVA, $F_{5,66}=2.467 ; p=0.000$ ). However, in June, no such positive response of $C$. glomerata and $S$. tenue was observed as total biovolume of the two species was very small (Fig. 6). In both the study periods, total biovolume of Phormidium ambiguum (ANOVA, $F_{5,66}=2.921 ; p=0.019$ ) and Oscillatora limosa (ANOVA, $F_{5,66}=3.051 ; p=0.015$ ) increased in all the nutrient treatments (Fig. 6). Lyngbya allorgei also showed similar response with increased biovolume in all the nutrient treatments (ANOVA, $F_{5,30}=650.123$; $p=0.000$. However, in March, the relative abundance of $L$. allorgei was low enough for inclusion in cell count data.

\section{Discussion}

A significant effect of seasonality was evident in periphytic community response to nutrient enrichment. The observed temporal differences may be due to varying environmental conditions as well as seasonal algal succession. The river exhibited differential limnological conditions, which was the major driving force for changes in periphytic community structure in the two study periods. During the spring, there was dominance of diatoms as well as green algae, whereas in summer there was absolute dominance of cyanobacteria. Similar patterns of seasonal succession of algae have also been 


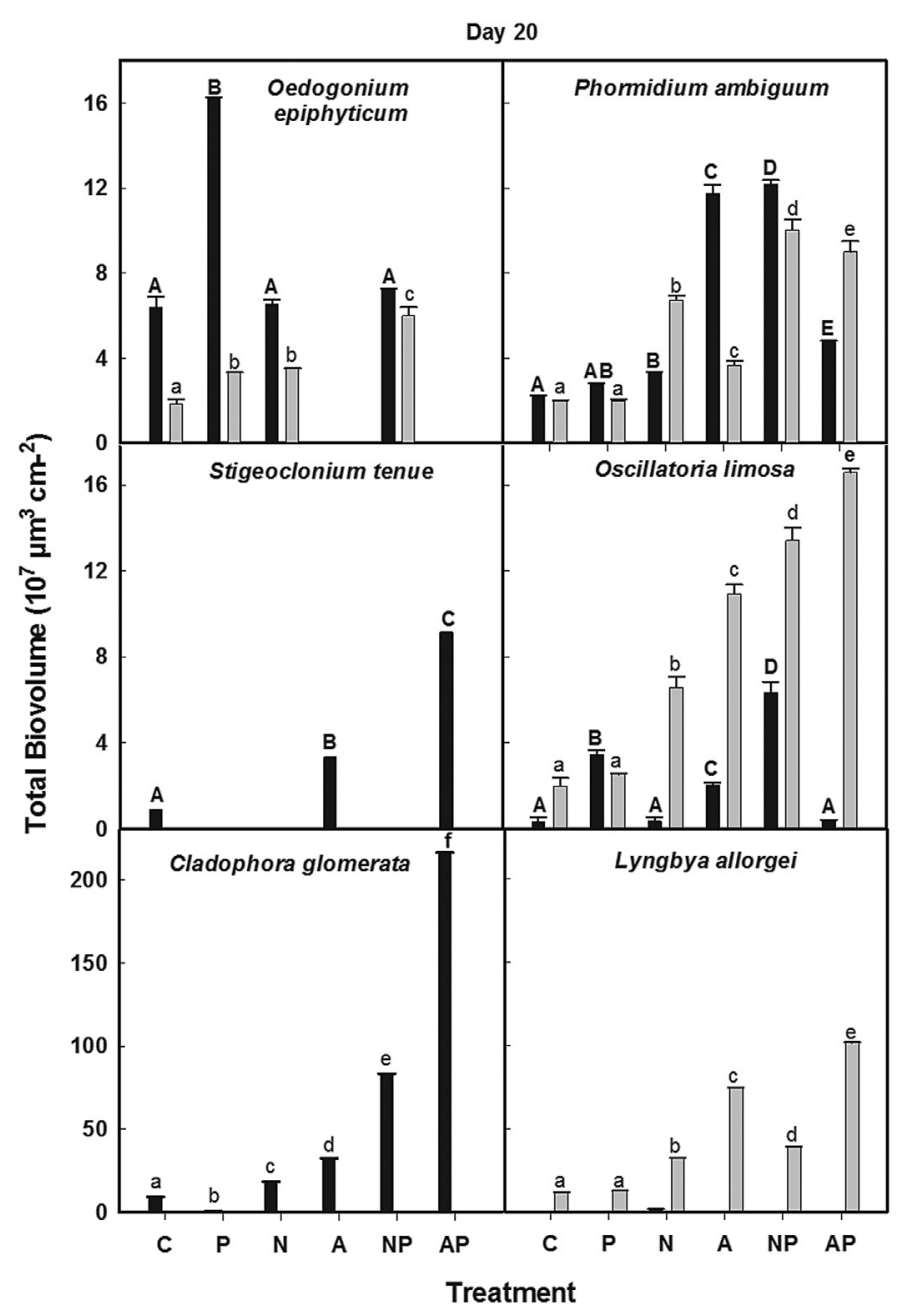

Fig. 6. Total biovolume of major green algae and cyanobacterial species growing on nutrient-releasing CDS for 20 days in March and June. $\mathrm{C}=$ control, $\mathrm{P}=\mathrm{PO}_{4}{ }^{3-}-\mathrm{P}, \mathrm{N}=\mathrm{NO}_{3}{ }^{-}-\mathrm{N}, \mathrm{A}=\mathrm{NH}_{4}{ }^{+}-\mathrm{N}, \mathrm{NP}=\mathrm{NO}_{3}{ }^{-}-\mathrm{N}+\mathrm{PO}_{4}{ }^{3-}-\mathrm{P}, \mathrm{AP}=\mathrm{NH}_{4}{ }^{+}-\mathrm{N}+\mathrm{PO}_{4}{ }^{3-}-\mathrm{P}$. Data bearing different letters for a particular time period, uppercase for March and lowercase for June, are statistically different from each other $(p<0.05$, Tukey's HSD test).

reported earlier (Allan, 1995; Teubner, 2000; Liboriussen, 2003; Pfeiffer et al., 2013).

Despite the temporal variabilities in various limnological parameters, the pattern of nutrient limitation was similar in the two study periods. Nitrogen appeared to be the primary limiting nutrient, in both the study periods. Enhancement of periphytic biomass by $\mathrm{NO}_{3}{ }^{-} \mathrm{N}$ enrichment, singly or in combination with $\mathrm{PO}_{4}{ }^{3-}-\mathrm{P}$ as observed in the present study, is in agreement with previous researchers (Francoeur, 2001; Death et al., 2007). A relatively greater biomass in combined nutrient enrichments $\left(\mathrm{NO}_{3}{ }^{-} \mathrm{N}+\mathrm{PO}_{4}{ }^{3-}-\mathrm{P}\right.$ and $\mathrm{NH}_{4}{ }^{-} \mathrm{-N}+$ $\mathrm{PO}_{4}{ }^{3}-\mathrm{P}$ ) than in individual nutrient enrichments, observed in both the study periods, indicated secondary growth limitation by phosphorus. Earlier, it was widely believed that freshwater systems are generally phosphorus limited, whereas marine systems are nitrogen limited (Paerl et al., 2014). Nevertheless, review of earlier bioassays conducted throughout the world (Dodds and Welch, 2000) as well as meta-analysis and synthesis (Francoeur, 2001; Elser et al., 2007) have shown that nitrogen limitation is also common in freshwater lakes and streams, which is reaffirmed by the present study as well. It needs mention that which nutrient limits growth under which conditions needs critical examination (Death et al., 2007).

The periphytic biomass responded sensitively to nutrient amendments and differed greatly in the two seasons. On all nutrient-releasing $\mathrm{CDS}$, except for those diffusing $\mathrm{PO}_{4}{ }^{3-}-\mathrm{P}$, significantly more biomass, almost two- to threefold greater, occurred in March than in June. Likewise, a higher periphytic biomass in spring and early summer than in late summer and fall was also reported by Allen and Hershey (1996). Stevenson et al. (2012) also noted greater biomass of periphyton in spring than in summer. The algal biomass with chl $a$ value $\geq 100$ $150 \mathrm{mg} \mathrm{m}^{-2}$ has been suggested as "nuisance" (Welch et al., 1988). In the present study, the nuisance level was attained at only one instance in $\mathrm{NO}_{3}{ }^{-}-\mathrm{N}+\mathrm{PO}_{4}{ }^{3-}$-P-enriched $\mathrm{CDS}$ after 20 days of colonization in March. The present observations of seasonal differences in periphytic biomass may be due to timedependent variability in periphyton community composition.

Taxonomic composition of periphyton often follows a seasonal trend in lakes and rivers (Allan, 1995). Diatoms dominate during winter and spring, whereas other groups particularly green algae and cyanobacteria become abundant 
during summer (Allan, 1995; Teubner, 2000; Liboriussen, 2003; Pfeiffer et al., 2013). The seasonal pattern may appear due to variations in various physicochemical parameters including nutrients, light and temperature. Temperature plays a key role in determining algal growth; cyanobacteria generally grow better at higher temperature than diatoms, which are better adapted to comparatively low temperatures (Lürling et al., 2013). In the present study, the two time periods, respectively representing spring and late summer, displayed large-scale differences in atmospheric temperature. Thus, higher atmospheric temperature in June favoured the dominance of cyanobacteria, whereas comparatively lower temperature in March encouraged greater abundance of diatoms.

According to Casterlin and Reynolds (1977), the algal species that respond to nutrient enrichment are generally those that are simultaneously favoured by water temperature as well as intensity of light, such as cyanobacteria in the late summer and Bacillariophyta in winter and spring. In the present study, also the algal group responded to nutrient enrichment in March and June depending on the predominant group, which increased its abundance following nutrient enrichment. In March, diatoms responded most favourably to nutrient treatments followed by green algae, whereas in June cyanobacteria were most responsive to enrichment than others.

$\mathrm{NH}_{4}{ }^{+}-\mathrm{N}$ better supported the growth of the community than $\mathrm{NO}_{3}{ }^{-} \mathrm{N}$ and this observation is in agreement with the widely held view that $\mathrm{NH}_{4}{ }^{+}-\mathrm{N}$ is the best for algal growth as, unlike $\mathrm{NO}_{3}{ }^{-}-\mathrm{N}$ that needs to be reduced in the cell, it can be directly assimilated (Glibert et al., 2016). However, many algae do not prefer $\mathrm{NH}_{4}{ }^{+}-\mathrm{N}$ for their growth (Glibert et al., 2016). A group-specific preference for $\mathrm{NH}_{4}{ }^{+}-\mathrm{N}$ was also evident in the present study, particularly by green algae and cyanobacteria that was primarily dependent on season. The total biovolume of green algae increased markedly in $\mathrm{NH}_{4}{ }^{+}$$\mathrm{N}+\mathrm{PO}_{4}{ }^{3-}-\mathrm{P}$ treatment in March, suggesting abundance of some $\mathrm{NH}_{4}{ }^{+}-\mathrm{N}$ loving algae. The stronger preference for $\mathrm{NH}_{4}{ }^{+}-\mathrm{N}$ was also displayed by cyanobacteria, however, in June. Although cyanobacteria could grow efficiently in both $\mathrm{NO}_{3}{ }^{-}-\mathrm{N}$ and $\mathrm{NH}_{4}{ }^{+}-\mathrm{N}$, an appreciably greater biovolume was recorded in $\mathrm{NH}_{4}{ }^{+}-\mathrm{N}$ and $\mathrm{NH}_{4}^{+}-\mathrm{N}+\mathrm{PO}_{4}{ }^{3-}-\mathrm{P}$ treatments. Some previous studies also report preferential utilization of ammonia by green algae and cyanobacteria (Domingues et al., 2011; Donald et al., 2013; Glibert et al., 2016).

Species richness and diversity of periphyton generally decrease following nutrient enrichment (Tilman, 1982). A reduction in species diversity was observed in both the study periods in almost all the nutrient treatments. This seemed to have happened due to reduced population size or disappearance of certain species on account of competitive interactions. Species richness decreased similarly in March; nevertheless, it increased in June in various nutrient treatments. The differential response of richness might be because of differences in community structure in two study periods. An increase in species richness following nutrient treatment has also been reported in some previous studies (Hillebrand et al., 2007; Larson and Passy, 2013). Tilman's "resource richness species richness" theory (1982) best explains the increase in richness. According to this, in resource poor habitats, the diversity may get increased with increasing resources through a narrow range.
During its development through various colonization stages, the periphytic biofilms experienced many allogenic and autogenic changes, including differential availability of light, nutrient and space as well as biotic interactions among species. In early growth phase, the biofilm was comparatively thin and there was little competition for light, space and nutrients. However, in late colonization period, the biofilm thickened due to heavy periphytic growth that increased the competition for resources. These biotic and abiotic changes in the vicinity of microbial biofilms prompted constant changes in biomass and other structural attributes of periphyton along the colonization period.

The populations of various periphytic taxa were differently influenced by nutrient enrichment in March as well as in June. This was because the algal species differed in their ability in utilizing various resources whose availability also varied with time. The increased biovolume of $N$. palea in $\mathrm{NH}_{4}{ }^{+}-\mathrm{N}$ and $\mathrm{NO}_{3}{ }^{-}-\mathrm{N}$ enrichment during both the study periods suggests its preference for high nitrogen concentration. Its similar response has been earlier reported from other geographical locations (Lowe, 1974; Pringle and Bowers, 1984; Marks and Power, 2001). N. palea also showed increased abundance in combined nutrient treatments $\mathrm{NO}_{3}{ }^{-}-\mathrm{N}+\mathrm{PO}_{4}{ }^{3-}-\mathrm{P}$ and $\mathrm{NH}_{4}{ }^{+}-\mathrm{N}+$ $\mathrm{PO}_{4}{ }^{3-}$-P. Some previous studies have also reported this species to be one of the abundant taxa under $\mathrm{NO}_{3}{ }^{-}$$\mathrm{N}+\mathrm{PO}_{4}{ }^{3-}-\mathrm{P}$ enrichment, thereby showing its liking for high nutrient concentration (Felisberto et al., 2011; Larson and Passy 2012). Incidentally, $N$. palea has been included in the list of algal species most tolerant to organic pollution (Palmer, 1969).

The total biovolume of $A$. granulata increased in all the nutrient treatments, thereby suggesting its preference for high nutrient concentration. Differential response to nutrient treatment in various stages of colonization was also displayed by some taxa, such as Cyclotella meneghiniana. An increase in total biovolume of this species on all the CDS was found in early colonization stage, i.e. up to day 10; however, its biovolume decreased subsequently probably due to excessive growth and dominance of late colonizing filamentous green algae and cyanobacteria. Fairchild and Lowe (1984) also observed a similar decline in total biovolume of $C$. meneghiniana in response to nutrient addition after 35 days of experiment.

Green algae also varied in their response to various nutrient treatments. $S$. tenue was greatly abundant on CDS releasing $\mathrm{NH}_{4}{ }^{+}-\mathrm{N}$, individually or in combination with $\mathrm{PO}_{4}{ }^{3-}$-P. Similar response of Stigeocolonium sp. occurred in a stream contaminated by effluents from pig farm and subjected to eutrophication by $\mathrm{NH}_{4}{ }^{+}-\mathrm{N}$ and $\mathrm{PO}_{4}{ }^{3-}-\mathrm{P}$ (Francke and Den Oude, 1983). Palmer (1969) also lists S. tenue as the sixth most tolerant algal species under organic pollution. Increased abundance of $S$. tenue following nitrogen, particularly $\mathrm{NO}_{3}{ }^{-}$$\mathrm{N}$ treatment, has also been reported earlier (Luttenton and Lowe, 2006). Contrary to earlier investigations, this taxon was absent in both the $\mathrm{NO}_{3}{ }^{-}-\mathrm{N}$ enrichments in the present study. This seems to have occurred due to accelerated growth of $C$. glomerata, which outcompeted $S$. tenue and displaced other taxa also. $\mathrm{PO}_{4}{ }^{3-}$-P enrichment also had no significant effect on the growth of this $S$. tenue. In a previous study also, $S$. tenue did not respond to either $\mathrm{NO}_{3}{ }^{-}-\mathrm{N}$ or $\mathrm{PO}_{4}{ }^{-}-\mathrm{P}$ alone (Fairchild et al., 1985). 
Increased abundance of $C$. glomerata on nitrogendiffusing substrates revealed its strong affinity for $\mathrm{NO}_{3}{ }^{-}-\mathrm{N}$. A strong correlation between Cladophora biomass and nitrate level has also been reported earlier (Stevenson et al., 2006; Penick et al., 2012). The positive response of Oedogonium sp. to $\mathrm{PO}_{4}{ }^{3-}$-P enrichment is in agreement with several previous studies (Schneider and Lindstrøm, 2011; Stevenson et al., 2012). Cladophora and Oedogonium spp. have often been reported as predominant algal taxa in eutrophic water bodies in addition to some bloom forming cyanobacterial species (Stevenson et al., 2012).

The cyanobacterial species constituting the dominant algal group in June responded strongly to all the nutrient treatments. The total biovolume of Oscillatoriales, such as Oscillatoria limosa, P. ambiguum and L. allorgei greatly increased in all the nutrient treatments in both the study periods. Similar response of Oscillatoriales was also reported by Douterelo et al. (2004) who found the prevalence of Lyngbya and Oscillatoria spp. at downstream river sites with high nutrient content in Spain. The increased abundance of Phormidium sp. following nutrient enrichment, as observed in the present study, is in consonance with Larson and Passy (2012), who documented the dominance of Phormidium inundatum in a laboratory stream treated with increased supply of nitrogen and phosphorus and subjected to high current velocity during late successional stage. The species belonging to Oscillatoria, Phormidium and Lyngbya have often been found in nutrient-enriched conditions and serve as bioindicators of eutrophication (Douterelo et al., 2004; Mateo et al., 2015).

As of now, the situation is not alarming in the river Ganga as the biomass of periphytic algae is well below the level considered as nuisance. But increase in concentration of nutrients may trigger excessive periphytic growth, which may assume nuisance proportion. Of the various periphytic species that responded favourably to nutrient enrichment in the present study, many are included in Palmer's list of species tolerant to organic pollution (Palmer, 1969). These algal taxa might turn out to be essential biomonitoring tool for the assessment of nutrient load in the river.

\section{Conclusions}

In conclusion, nutrient enrichment effect on periphyton was dependent on season because of time-scale variability in composition of periphytic community. Periphytic growth in the river was primarily $\mathrm{N}$ limited and showed secondary limitation by $\mathrm{P}$. The enrichment effects were more pronounced in March than June, which showed a much favorable biomass development up to nuisance level. Reduction of species diversity was one of the major changes that nutrient enrichment brought about in a periphytic community. Importance of colonization time seemed noteworthy in designing and development of programmes to monitor and control eutrophication. This study presented the results from the spring and summer seasons and it is required to conduct the experiments in other times of the year also to target appropriate management strategies to reduce nutrient load.

Acknowledgements. We thank the Head of Department, Department of Botany, and the Coordinator, Centre of Advanced Study in Botany, Institute of Science, Banaras
Hindu University, for providing necessary facilities. The authors sincerely acknowledge Prof. J. P. Gaur, Department of Botany, BHU, Varanasi, who has supervised this research work and provided valuable guidance for the preparation of this manuscript. A.Y. thanks the University Grants Commission, New Delhi, for the financial support in the form of a fellowship.

\section{References}

Allan JD. 1995. Stream Ecology: Structure and Function of Running Waters, London: Chapman \& Hall.

Allen NS, Hershey AE. 1996. Seasonal changes in chlorophyll $a$ response to nutrient amendments in a North Shore tributary of Lake Superior. J N Am Benthol Soc 15: 170-178.

Ansari AA, Gill SS, Lanza GR, Rast W, eds. 2011. Eutrophication: Causes, Consequences and Control, New York: Springer Science+Business Media B.V.

Biggs BJF, Kilroy C. 2000. Stream Periphyton Monitoring Manual. Prepared for the New Zealand Ministry for the Environment, Chirstchurch, New Zealand: NIWA.

Casartelli MR, Ferragut C. 2015. Influence of seasonality and rooted aquatic macrophytes on periphytic algal community on artificial substratum in a shallow tropical reservoir. Int Rev Hydrobiol 100: $158-168$

Casterlin ME, Reynolds WW. 1977. Seasonal algal succession and cultural eutrophication in a north temperate lake. Hydrobiologia 54: 99-108.

Cox EJ. 1996. Identification of Freshwater Diatoms from Live Material, London: Chapman \& Hall.

Death RG, Death F, Ausseil OMN. 2007. Nutrient limitation of periphyton growth in tributaries and the mainstem of a central North Island river, New Zealand. N Z J Mar Freshwater Res 41: 273-281.

DeNicola DM, de Eyto E, Wemaere A, Irvine K. 2006. Periphyton response to nutrient addition in 3 lakes of different benthic productivity. J N Am Benthol Soc 25: 616-631.

Desikachary TV. 1959. Cyanophyta, New Delhi: Indian Council of Agricultural Research.

Dodds WK. 2003. The role of periphyton in phosphorus retention in shallow freshwater aquatic systems. $J$ Phycol 39: 840-849.

Dodds WK, Smith VH, Lohman K. 2002. Nitrogen and phosphorus relationship to benthic algal biomass in temperate streams. Can J Fish Aquat Sci 59: 865-874.

Dodds WK, Smith, VH. 2016. Nitrogen, phosphorus, and eutrophication in streams. Inland Waters 6: 155-164.

Dodds WK, Welch EB. 2000. Establishing nutrient criteria in streams. J N Am Benthol Soc 19: 186-196.

Domingues RB, Barbosa AB, Sommer U, Galvão HM. 2011. Ammonium nitrate and phytoplankton interactions in a freshwater tidal estuarine zone: potential effects of cultural eutrophication. Aquat Sci 73: 331-343.

Donald DB, Bogard MJ, Finlay K, Bunting L, Leavitt PR. 2013. Phytoplankton-specific response to enrichment of phosphorus-rich surface waters with ammonium, nitrate and urea. PLoS One 8: e53277.

Douterelo I, Perona E, Mateo P. 2004. Use of cyanobacteria to assess water quality in running waters. Environ Pollut 127: 377-384.

Elser JJ, Bracken MES, Cleland EE, Gurner DS, Harpole WS, Hillebrand H, Ngai JT, Seabloom EW, Shurin JB, Smith JE. 2007. Global analysis of nitrogen and phosphorus limitation of primary producers in freshwater, marine and terrestrial ecosystems. Ecol Lett 10: 1135-1142. 
Fairchild GW, Lowe RL. 1984. Artificial substrates which release nutrients: effects on periphyton and invertebrate succession. Hydrobiologia 114: 29-37.

Fairchild GW, Lowe RL, Richardson WB. 1985. Algal periphyton growth on nutrient-diffusing substrates: an in situ bioassay. Ecology 66: 465-472.

Felisberto SA, Leandrini JA, Rodrigues L. 2011. Effects of nutrients enrichment on algal communities: an experimental in mesocosms approach. Acta Limnol Bras 23: 28-137.

Franca RCS, Lopes MRM, Ferragut C. 2009. Temporal variation of biomass and status nutrient of periphyton in shallow Amazonian Lake (Rio Branco, Brazil). Acta Limnol Bras 21: 175-183.

Francke JA, Den Oude PJ. 1983. Growth of Stigeoclonium and Oedogonium species in artificial ammonium-N and phosphate-P gradients. Aquat Bot 15: 375-380.

Francoeur SN. 2001. Meta-analysis of lotic nutrient amendment experiments: detecting and quantifying subtle responses. $J \mathrm{~N} \mathrm{Am}$ Benthol Soc 20: 358-356.

Glibert PM, Wilkerson FP, Dugdale RC, Raven JA, Dupont CL, Leavitt PR, Parker AE, Burkholder JM, Kana TM. 2016. Pluses and minuses of ammonium and nitrate uptake and assimilation by phytoplankton and implications for productivity and community composition with emphasis on nitrogen-enriched conditions. Limnol Oceanogr 61: 165-197.

Gordon ND, McMahon TA, Finlayson BL, Gippel CJ, Nathan RJ. 2013. Stream hydrology: an introduction for ecologists, 2nd ed., Chichester, UK: John Wiley \& Sons, Inc.

Hill BH, Stevenson RJ, Pan Y, Herlihy AT, Kaufmann PR, Johnson CB. 2001. Comparison of correlations between environmental characteristics and stream diatom assemblages characterized at genus and species levels. $J N$ Am Benthol Soc 20: 299-310.

Hillebrand H, Dürselen CD, Kirschtel D, Pollingher U, Zohary T. 1999. Biovolume calculation for pelagic and benthic microalgae. J Phycol 35: 403-424.

Hillebrand H, Gruner DS, Borer ET, Bracken MES, Cleland EE, Elser JJ, Harpole WS, Ngai JT, Seabloom EW, Shurin JB, Smith JE. 2007. Consumer versus resource control of producer diversity depends on ecosystem type and producer community structure. Proc Natl Acad Sci USA 104: 10904-10909.

Jarvie HP, Neal C, Warwick A, White J, Neal M, Wickham HD, Hill LK, Andrews MC. 2002. Phosphorus uptake into algal biofilms in a lowland chalk river. Sci Total Environ 282-283: 353-373.

Jin L, Whitehead PG, Sarkar S, Sinha R, Futter MN, Butterfield D, Caeser J, Crossman J. 2015. Assessing the impacts of climate change and socio-economic changes on flow and phosphorus flux in the Ganga river system. Environ Sci Process Impacts 17: 1098-1110.

Keck F, Lepori F. 2012. Can we predict nutrient limitation in streams and rivers? Freshw Biol 57: 1410-1421.

Larson CA, Passy SI. 2012. Taxonomic and functional composition of the algal benthos exhibits similar successional trends in response to nutrient supply and current velocity. FEMS Microbiol Ecol 80: 352-362.

Larson CA, Passy SI. 2013. Rates of species accumulation and taxonomic diversification during phototrophic biofilm development are controlled by both nutrient supply and current velocity. Appl Environ Microbiol 79: 2054-2060.

Lawrence JR, Chenier MR, Roy R, Beaumier D, Fortin N, Swerhone, GDW, Neu, TR. Greer CW. 2004. Microscale and molecular assessment of impacts of nickel, nutrients and oxygen level on structure and function of river biofilm communities. Appl Environ Microbiol 70: 4236-4339.

Liboriussen L. 2003. Production, regulation and ecophysiology of periphyton in shallow freshwater lakes. $\mathrm{PhD}$ thesis, National
Environmental Research Institute, Department of Freshwater Ecology, Faculty of Science, University of Aarhus, Denmark, $47 \mathrm{p}$.

Lowe RL. 1974. Environmental Requirements and Pollution Tolerances of Freshwater Diatoms, EPA-670/4-74-005, U.S. Environmental Protection Agency, Cincinnati, $\mathrm{OH}$.

Lürling M, Eshetu F, Faassen EJ, Kosten S, Huszar, VLM. 2013. Comparison of cyanobacterial and green algal growth rates at different temperatures. Freshw Biol 58: 552-559.

Luttenton MR, Lowe RL. 2006. Response of a lentic periphyton community to nutrient enrichment at low $\mathrm{N}: \mathrm{P}$ ratios. $J$ Phycol 42 : 1007-1015.

Lyon DR, Ziegler SE. 2009. Carbon cycling within epilithic biofilm communities across a nutrient gradient of headwater streams. Limnol Oceanogr 54: 439-449.

Marks JC, Power ME. 2001. Nutrient induced changes in the species composition of epiphytes on Cladophora glomerata Kütz. (Chlorophyta). Hydrobiologia 450: 187-196.

Mateo P, Leganés F, Perona E, Loza V, Fernández-Piñas, F. 2015. Cyanobacteria as bioindicators and bioreporters of environmental analysis in aquatic ecosystems. Biodivers Conserv 24: 909-948.

Paerl HW, Hall NS, Peierls BL, Rossignol KL. 2014. Evolving paradigms and challenges in estuarine and coastal eutrophication dynamics in a culturally and climatically stressed world. Estuar Coast 37: 243-258.

Palmer CM. 1969. A composite rating of algae tolerating organic pollution. J Phycol 5: 78-82.

Pandey LK, Kumar D, Yadav A, Rai J, Gaur JP. 2014. Morphological abnormalities in periphytic diatoms as a tool for biomonitoring of heavy metal pollution in a river. Ecol Indic 36: 272-279.

Patrick R, Reimer CW. 1966. Diatoms of the United States, Exclusive of Alaska and Hawaii, Vol. I, Monograph No. 13, Philadelphia, PA: Academy of Natural Sciences of Philadelphia.

Patrick R, Reimer CW. 1975. The Diatoms of the United States, Vol. 2, Part 1, Monograph No. 13, Philadelphia, PA: Academy of Natural Sciences of Philadelphia.

Penick MD, Grubbs SA, Meier AJ. 2012. Algal biomass accrual in relation to nutrient availability and limitation along a longitudinal gradient of a karst riverine system. Int Aquat Res 4: 1-13.

Petersen CR, Jovanovic NZ, Grenfell MC, Oberholster PJ, Cheng P. 2018. Responses of aquatic communities to physical and chemical parameters in agriculturally impacted coastal river systems. Hydrobiologia 813: 157-175.

Pfeiffer TZ, Mihaljević M, Stević F, Špoljarić D. 2013. Periphytic algae colonization driven by variable environmental components in a temperate floodplain lake. Ann Limnol - Int J Lim 49: 179-190.

Phillipose MT. 1967. Chlorococcales, New Delhi: Indian Council of Agriculture Research.

Prescott GW. 1962. Algae of the Western Great Lakes Area, Dubuque, Iowa: Wm. C. Brown Company.

Prescott GW. 1978. How to know the freshwater algae, 3rd ed., Dubuque, IA: Wm. C. Brown Company.

Pringle CM, Bowers, JA. 1984. An in situ substratum fertilization technique: diatom colonization on nutrient-enriched, sand substrata. Can J Fish Aquat Sci 41: 1247-1251.

Proia L, Romaní AM, Sabater S. 2012. Nutrients and light effects on stream biofilms: a combined assessment with CLSM, structural and functional parameters. Hydrobiologia 695: 281-291.

Schneider SC, Lindstrøm E.-A. 2011. The periphyton index of trophic status PIT: a new eutrophication metric based on non-diatomaceous benthic algae in Nordic rivers. Hydrobiologia 665: 143-155.

Shannon CE. 1948. A mathematical theory of communication. Bell Syst Tech J 27: 379-423. 
Stevenson RJ, Rier ST, Riseng CM, Schultz RE, Wiley MJ. 2006. Comparing effects of nutrients on algal biomass in streams in two regions with different disturbance regimes and with applications for developing nutrient criteria. Hydrobiologia 561: 149-165.

Stevenson RJ, Bennett BJ, Jordan DN, French RD. 2012. Phosphorus regulates stream injury by filamentous green algae, $\mathrm{DO}$, and $\mathrm{pH}$ with thresholds in responses. Hydrobiologia 695: 25-42.

Strickland JDH, Parsons TR. 1968. A Practical Handbook of Seawater Analysis, 2nd ed., Ottawa: Fisheries Research Board of Canada.

Tank JL, Dodds WK. 2003. Nutrient limitation of epilithic and epixylic biofilms in 10 North American streams. Freshwater Biol 48: 1031-1049.

Teissier S, Torre M, Delmas F, Garabétian F. 2007. Detailing biogeochemical $\mathrm{N}$ budgets in riverine epilithic biofilms. $J \mathrm{~N} \mathrm{Am}$ Benthol Soc 26: 178-190.

Teubner K. 2000. Synchronised changes of planktonic cyanobacterial and diatom assemblages in North German waters reduce seasonality to two principal periods. Arch Hydrobiol 55: 565-580.
Tilman D. 1982. Resource Competition and Community Structure Princeton, NJ: Princeton University Press.

Townsend SA, Garcia EA, Douglas MM. 2012. The response of benthic algal biomass to nutrient addition over a range of current speeds in an oligotrophic river. Freshw Sci 31: 1233-1243.

Vollenweider RA. 1976. Advances in defining critical loading levels for phosphorus in lake eutrophication. Mem Ist Ital Idrobiol 33: 53-83.

Welch EB, Jacoby JM, Horner RR, Seeley MR. 1988. Nuisance biomass levels of periphytic algae in streams. Hydrobiologia 157: 161-168.

Wetzel RG, Likens GE. 2000. Limnological Analyses, 3rd ed., New York: Springer.

Whitehead PG, Sarkar S, Jin L, Futter MN, Ceasar J, Barbour E, Butterfield D, Sinha R, Nicholls R, Hutton C, Leckie HD. 2015. Dynamic modeling of the Ganga river system: impacts of future climate and socio-economic changes on flows and nitrogen fluxes in India and Bangladesh. Environ Sci Process Impacts 17: 1082-1097.

Cite this article as: Yadav A, Kumar D, Singh RS, Pandey LK, Rai J. 2018. Seasonal variations in response of periphytic algal community to nutrient enrichment in the river Ganga (Varanasi, India). Ann. Limnol. - Int. J. Lim. 54: 32 